Article

\title{
Crowding in or crowding out? Public Investment and Private Investment in South Africa: An ECM Approach
}

\author{
Author: Dumisani Pamba \\ ${ }^{1}$ School of Accounting, Economics and Finance, University of KwaZulu-Natal, Westville, Durban, \\ 4000, South Africa, 217076475@stu.ukzn.ac.za \\ * Correspondence: kanye.pamba@gmail.com
}

\begin{abstract}
This study aims to explore the link between public investment and private investment in South Africa, using time series data spanning 40 years (1980-2020). Private investment is subdivided into credit to private sector (CPS) and foreign direct investment (FDI). Several econometric methodologies were used in the study, including the unit root test, cointegration test, and Error Correction Method (ECM). The Phillips-Perron (PP) test results point out that all the variables are stationary at levels with the exception of public investment (PI) which is stationary at first difference. The co-integration test reveals that the variables have a long-run equilibrium relationship. According to the findings of the ECM, public investment has a negative relationship with private investment (as measured by credit to private sector and foreign direct investment). The conclusion implies that in South Africa, public investment crowds out private investment. Other results revealed that, RGDP crowds in credit to private sector while crowding out foreign direct investment. Finally, the ECM findings show that government consumption expenditure crowds out credit to private sector and foreign direct investment. The residuals are homoskedastic and show no serial correlation, indicating that the model is adequate, according to the test for adequacy.
\end{abstract}

Keywords: Credit to Private Sector; Foreign Direct Investment; Government Consumption Expenditure; Public Investment; Error Correction Model and South Africa.

\section{Introduction}

The impact of public investment and private investment on economic growth is long been a topic of debate in macroeconomics and development economics, and it has resurfaced in recent years. The influence among these two types of investment on economic growth and social environments is widely recognized (Hussein and Benhin, 2015). Since the dichotomy between public and private investment has an impact on economic growth, it is critical to comprehend the connections between the two. Private investment is essential for economic progress; even so, how public policy impacts private investment is a matter that has yet to be addressed (Erden and Holcombe, 2005). The majority of the public invested capital is spent on infrastructure (Gbenga et al., 2015). If this is the case, public investment may not only actively stimulate economic growth but also indirectly boost private investment. Good infrastructure, according to $\mathrm{Xu}$ and Yan (2014), may boost private investment efficiency and lower private sector costs of production, resulting in a beneficial influence on private investment profitability.

Neoclassical economists, on the other hand, argue that public investment crowds out private investment. According to Gbenga et al. (2015), this occurs when an increase in government capital spending is supported by borrowing, triggering interest rates to rise. On the assumption of full 
employment of resources, high interest rates, cause a drop in private investment. Based on the neoclassical assumption of full employment and market competitiveness in the absence of government intervention, it results in an increase in costs of borrowing that would be utilized to fund new private spending projects.

The second standpoint on the impact of government expenditure on private investment is the Ricardian Equivalence Theorem, which assumes that an increase in the deficit funded by fiscal expenditure will be matched by a future tax increase, leaving interest rates and private investment spending unchanged. To put it differently, a rise in budget deficits is likely to be followed by a tax hike in the future or now (Kustepeli, 2005). As a result, there is neither crowding out nor crowding in impact of fiscal expenditure since private investment and government spending are understood to function independently. If the government imposes additional taxes in the future, people and the private sector will have less disposable income, which would have a negative impact on private sector investment spending.

Uncertainty is another important issue that is affecting private investment. According to existing literature, rational investors often seek to trade off the benefits of greater knowledge received by postponing planned investment projects with the benefits from early commitment to invest in the economy during periods of macroeconomic uncertainty (Erden and Holcombe, 2005). The authors further argued that this behavior stems from the belief that the additional knowledge received during the waiting time might be crucial in making a major optimum investment decision. Furthermore, several research have looked at the influence of uncertainty on investment decisions in depth (see, among others, Dixit and Pindyck 1994; Abel and Eberly 1995). On the other side, Abel (1983) empirically shown that when uncertainty rises, the predicted value of marginal revenue capital goods rises, resulting in more investment. This critical examination is based on the idea that investors can expand or decrease their work force at any time while their capital stays the same. As a result, uncertainty may have a significant impact on both the long-run and short-run patterns of investment decisions, and it should be considered in an empirical study of the impact of public investment on private investment.

Investment is essential for economic development since it boosts productivity, employment, and technological advancement (Hussein and Benhin, 2015). However, based on the above debate, it is still unclear whether public investment, like private investment, has a positive or negative impact on economic growth. Furthermore, there is an increasing body of empirical evidence supporting of a public-led economic growth process (see, among others, Aschauer, 1989b; Belloc and Vertova, 2004). Tatom (1991), Holtz-Eakin (1994), and Evans and Karras (1994) concluded, that public investment had a little effect on productivity. However, there are studies that attribute economic growth to private investment (Khan and Reinhart, 1990; Ghura, 1997; Hague, 2013, among others). These studies discovered that, while public investment helps emerging nations' economies to function better, private investment has a greater impact on economic growth. According to Chete and Akpokodje (1997), governments have attempted to influence the amount of investment in emerging economies because of the critical role of private investment in development renewal. When private sector investment is low, the authors believe that the government should intervene with strong monetary and fiscal measures to boost it.

The question of whether public investment and private investment are substitutes or supplements is a contentious issue in macroeconomic theory and policy. According to Wang (2005), public investment spending can enable new private capital accumulation and thereby stimulate economic growth by influencing private sector economic activity. Makuyana and Odhiambo (2016) suggest that 
public investment in infrastructure projects such as education, electricity production and transmission, motorways, roads, as well as water supply and sewerage systems typically boosts private capital's marginal productivity. The availability of these basic infrastructures lowers the cost of doing business in the private sector. This arrangement generates a favorable climate for additional private-sector investment and production growth. Aschauer (1989a), on the other hand, emphasized that the precise impact of government spending on private investment is dependent on the form of government spending considered. For a group of African nations, Oshikoya (1994) provided evidence that public infrastructure (represented by expected public investment) has a positive influence on private investment, but non-infrastructure investment (the unexpected component) has a negative impact. A research headed by Ekpo (1996) found that capital spending on transportation and communication, agriculture, health, and education drew in private investment, whereas construction and industrial drove out private investment.

The influence of government spending on private investment has become a significant subject in policy discussions in South Africa since 1994, when the government began to adopt an expansionary fiscal policy. Government has a significant role in growing economies like South Africa, both in terms of scope and importance for faster economic progress.

The Keynesian perspective promotes government intervention in the economy. According to Gbenga et al., (2015), more government spending boosts domestic economic activity, drawing in private sector investment expenditures. According to the Keynesian viewpoint, it is unusual for an economy to stay at full employment all of the time, therefore investment responsiveness to interest rates would be minimal. In such situation, expansionary fiscal policy, i.e., a rise in government spending, will result in minor or no interest rate hikes, hence increasing the economy's production and income. Public investment in infrastructure projects such as education, energy, airports, motorways, roads, water supply, and sewage systems frequently boosts private capital's marginal productivity. According to Fedderke et al., (2006), there is significantly greater empirical evidence that infrastructure investment may contribute to increased productivity in South Africa. The cost of private sector investment is reduced owing to the accessibility of these fundamental infrastructures. Infrastructure, according to Heymans and Thome-Erasmus (1998), contributes to growth by dipping production and consumption costs, therefore enhancing service delivery and development results. The South African government has enhanced its partnership with private-sector investors in order to expedite the execution of structural reforms outlined in the National Development Plan (NDP) (Budget Review, 2016). These policy reforms will stimulate more private investment spending and make conducting business in South Africa easier. Furthermore, this collection of policy documents and efforts has highlighted infrastructure investment as a key component in firmly establishing South Africa's high-growth trajectory (Mbanda and Chitiga, 2013). Human capital, productive capacity, and infrastructure are also highlighted in the NDP as requirements for a more equal and inclusive South Africa (NPC, 2012).

According to a World Bank (2017) report, private investment has shifted to less productive industries in recent years, resulting in negative total factor productivity growth in South Africa. Since 2012, capital has flowed to sectors with declining capital productivity, such as mining, electricity, transportation, and other services, rather than sectors with increasing capital productivity, such as agriculture, manufacturing, construction, trade, and finance, according to the report, lowering average capital productivity. Kollamparambil and Nicolaou (2011) examined the nature and relationship between public expenditure and private investment in South Africa using quarterly data from 1960 to 2005. They discovered that, while public investment does not crowd in or crowd out private investment, 
it does have an indirect impact on private investment through the accelerator effect. The intriguing question is whether or not this study will provide comparable outcomes.

To my knowledge, there is a lack of empirical research on the link between public investment spending and private sector investment in South Africa. The study splits private investment into two categories: foreign direct investment and private domestic investment. The question of particular relevance is whether there is a significant relationship in South Africa between public investment and private investment. As a result, the primary objective of this study is to discover the possible link between public investment and private investment spending. We should expect a positive link between public investment spending and private investment behavior in theory. This is because an increase in public investment spending is expected to boost economic growth by increasing the pace of economic activity. Public investment spending, according to Keynesian economists, is a beneficial instrument for the government to use in addressing the problem of growth in an economy due to market failures. According to Keynesian economists, the private sector is inclined to make poor decisions at times and, as a result, invest in inefficient initiatives that result in inefficient outcomes. To stabilize productivity throughout business cycles, appropriate economic policy responses such as monetary policy measures by the central bank and fiscal policy by the government can be used.

The paper is structured as follows after the introduction in Section 1: The literature review is presented in Section 2, and the data, model specification, and technique are discussed in Section 3. Section 4 presents and examines the empirical findings, and Section 5 brings the research to a close.

\section{Literature Review.}

\subsection{Empirical Literature.}

The influence of public investment on private investment behavior is still a contentious topic. The research on the influence of public and private investment on economic growth assumes a crowdingin and crowding-out relationship between public and private investment. The number of empirical studies on the crowding impact of public investment on private investment is both enormous and insufficient. Toshiya, (2010), who empirically researched the impacts of public investment on private investment using Japanese empirical data. The author confirmed the crowding-in impact of public investment on private investment by estimating the error correction model. Similarly, Narayan (2004) used the ECM to investigate the impact of public investment on private investment in Fiji. He split the sample into two groups, revealing cointegration between government and private investment between 1950 and 1975 and no cointegration between 1976 and 2001. For the first period, there was crowding-in of private investment by government investment, whereas for the second era, there was a statistically weak association. Wang (2005) conducted a research for Canada from 1961 to 2000 to determine the long-run impacts of government expenditure on gross private investment. The government spent money on education, health, capital, and infrastructure, as well as debt service expenses. He discovered that government spending on education and health had crowding-in effects on private investment, whereas government spending on capital, infrastructure, and debt charges had crowding-out effects. Furceri and Sousa (2009) investigated the influence of government expenditure on the private sector, determining whether crowding out or crowding in impacts existed. They show that government expenditure has significant crowding out effects, negatively affecting both private consumption and private investment, using panel data from 1960 to 2007. Similarly, Nazmi and Ramirez (1997) examine the influence of public and private investment spending in Mexico on economic growth. Public investment spending has a considerable and favorable impact on production growth. The impact of 
public investment on economic growth was statistically comparable to that of private capital investment. Public investment contributed to production growth at the expense of private investment, showing a considerable crowding out impact. For a sample of twenty-five developing nations in Africa, Asia, and Latin America from 1970 to 2000, Atukeren (2004) employed granger causality approach to better understand the link between public and private investment. His findings suggest that public investment attracts private investment.

However, there is a growing amount of empirical findings in favor of a government-led economic growth process. Mittnik and Newman (2001) used a VAR framework to assess the dynamic influence of public investment on economic growth in six industrialized economies, including the United States. They came to the conclusion that public investment is critical to economic growth.

Then there is the belief that public and private investments are unrelated to one another, and so their contributions to economic growth are distinct and complementary. In a wide group of developing nations, Khan and Reinhart (1990) examine the significance of public and private investment in driving economic growth. The findings of the study reveal that private and public investments have distinct effects on economic growth, with private investments having a much broader and direct impact than public investments. Changes in the efficacy of public and private investments were also observed.

There is a growing amount of empirical findings in favor of a public-private investment-led economic growth process. Aubyn and Afonso (2008) used the VAR framework to examine the macroeconomic returns of public and private investment in a sample of European nations, as well as Japan, Canada, and the United States. Their empirical findings revealed that, while both public and private investment boost production in the nations studied, the complementary impact of public investment on private investment differed by country. Hussein and Benhin (2015) looked at the impact of public and private investment on Iraqi economic growth from 1970 to 2010. The time series data was applied to cointegration and error correction methods. The empirical findings demonstrate that, in the long run, private investment, public investment, labor force and oil revenue growth have a positive and statistically significant impact on real GDP.

Mixed outcomes are supported by a large body of empirical studies. In the instance of small open economies, Sineviien (2015) looked at the link between government spending and private investment. Using data from Bulgaria, Estonia, Latvia, Lithuania, and Slovenia from 1996 to 2012, cross-correlations and Granger causality tests were performed. The findings show that, with the exception of Bulgaria, the impact of increased government spending on private investment is very weak, and that the negative impact of increased government spending on private investment dominates; however, the impact of increased private investment on government expenditure is very different in the countries studied.

The studies above shown that the link between private and public investment varies by country. Overall, the majority of research concluded that public and private investment had a crowding-in and crowding-out connection, with just a few studies finding no clear evidence to support these hypotheses. However, there is a growing amount of empirical evidence supporting either a public investment-led or a private investment-led economic growth process. There is also a belief that public and private investments are unrelated to one another. On the other hand, some argue that public investment should be used in conjunction with private investment. On the basis of these mixed findings, it is inappropriate to draw any conclusions about the possible link between public and private investment in South Africa.

In the majority of studies, the error correction model (ECM), co-integration, and the VAR model are used as statistical methods. Other statistical approaches, such as granger causality, were also used 
in several research. Finally, it is noted that the majority of the articles cover a higher number of nations, with the majority of them focused on developing countries and only a handful on developed countries.

\subsection{Limitations of Previous Studies.}

There is no dispute that empirical research in the fields of public and private investment in South Africa is limited. The majority of the research focused on the impact of government spending on economic growth, which may overlook the mechanism by which public investment spending might influence private investment (crowd in or crowd out). They only looked at the relationship between government expenditure and economic growth.

As a result, this study made a significant contribution by recognizing that public investment expenditure can influence private investment through a variety of channels, some of which are crowding in effects, while others are crowding out effects and/or complementary effects between public and private investment. In this study, private investment is subdivided into two categories: foreign direct investment and private domestic investment. This enables empirical research on the link between public investment and foreign direct investment, as well as the relationship between public investment and domestic private investment in South Africa. To the best of my knowledge, there is no empirical research in South Africa that breaks down private investment into domestic and foreign direct investment and uses private investment as a dependent variable.

\section{Methodology.}

\subsection{Data Measurement and Source.}

The South African Reserve Bank (SARB) statistical bulletin was used to extract annual time series data covering the period 1980-2020 to investigate the link between public investment and private investment in South Africa.

Table 1. Definition of the Variables in the Model and Data Source.

\begin{tabular}{cccc}
\hline $\begin{array}{l}\text { Variables } \\
\text { name }\end{array}$ & Variables description & Calculations & Source \\
\hline CPS & Private Investment & Total credit to the private sector & SARB \\
FDI & Private Investment & Total foreign direct investment & SARB \\
PI & Public Investment & Total gross fixed capital formation & SARB \\
RGDP & Real GDP per capita & Total Real GDP per capita & SARB \\
GCE & Government expenditure & Total government consumption expenditure & SARB \\
\hline
\end{tabular}

Credit to private sector (CPS) and foreign direct investment (FDI) are two indicators of private investment. Gross fixed capital formation (public corporations) is used to measure public investment, whereas Real GDP per capita (RGDP) is used to measure economic growth, and government consumption expenditure (GCE) is also included. All variables are converted to logarithms form.

\subsection{Model Specification.}

The study hypothesized that in South Africa, public investment crowds out private investment. The dependent variable in the model is private investment, whereas the independent variables are public investment, real GDP per capita, and government consumption expenditure. This study used a simple model to examine the link between variables: 


$$
\mathrm{PRV}_{t i}=f\left(\mathrm{PI}_{\mathrm{t}}, \mathrm{RGDP}_{\mathrm{t}}, \mathrm{GCE}_{\mathrm{t}}\right)
$$

In equation (1), the symbols $i$ stand for credit to private sector and foreign direct investment, while the subscript " $t$ " stands for current time. When we linearize equation (1), we get:

$$
\ln \mathrm{PRV}_{t i}=\alpha_{0}+\alpha_{1} \ln \mathrm{PI}_{\mathrm{t}}+\alpha_{2} \ln \mathrm{RGDP}_{\mathrm{t}}+\alpha_{3} \ln \mathrm{GCE}_{\mathrm{t}}+\mu_{\mathrm{t}}
$$

$\alpha_{0}$, is intercept, $\alpha 1$ to $\alpha_{3}$ are the slopes of the independent variable coefficients to be computed, and $t$ is the error term at time $t$. The long run regression equation (equation 2) is used to determine the long run connection between the variables. The relevant error correction equation is derived as follows to estimate the short-run connection among variables in equation (2):

$$
\Delta \ln \mathrm{PRV}_{t}=\alpha_{0}+\alpha_{1} \Delta \ln \mathrm{PI}_{\mathrm{t}-1}+\alpha_{2} \Delta \ln \mathrm{RGDP}_{\mathrm{t}-1}+\alpha_{3} \Delta \ln \mathrm{GCE}_{\mathrm{t}-1}+\psi \mathrm{ECM}_{\mathrm{t}-1}+\varepsilon
$$

$\Delta=$ change; $\psi=$ estimate of $\mathrm{ECM} ; \varepsilon=$ white noise residual; $\mathrm{t}-1=$ variable lagged by one period; $\mathrm{ECM} \mathrm{t}-1$ is the error correction term of the short run equation.

\subsection{Method of Analysis.}

The unit root test, co-integration test, and Error-Correction Methodology (ECM) techniques were used to investigate the link between public and private investment.

The Phillips-Perron (PP) unit root test is examined using a conventional technique in this work. According to Brooks (2008), this test is crucial since it reveals the data's structural breakdowns, trends, and stationarity. Since variables in time series analysis are in log form, they must be checked for stationarity before running the cointegration test. As a result, before employing this test, we use unit root test to identify the order of integration of all variables by testing for the null hypothesis $\mathrm{H}_{0}: \beta=0$ (i.e. has a unit root), and the alternative hypothesis is $\mathrm{H}_{1}: \beta<0$. To prevent erroneous results, all variables should be integrated at first order difference I(1). If the variables are non-stationary, 'spurious regression' can occur, causing the predicted coefficients to be biased. Confidence intervals and hypothesis tests will be unreliable as a result of this. By minimizing the Schwarz Information Criteria (SIC), the optimal lag length of the lagged differences of the tested variables is established. The unit root test was used to test for stationarity in all variables. When a non-stationary time series is discovered, unit root tests are employed to assess if the first or second differences of the variables are stationary.

The Dickey-Fuller test has a disadvantage over the Phillips-Perron test in that it does not account for potential autocorrelation in the error process, $\varepsilon$. Since the OLS estimates of coefficients are inefficient and t-ratios are skewed if $\varepsilon \mathrm{t}$ is auto-correlated, the Phillips-Perron test provides a more thorough model of unit root for non-stationarity. The Phillips-Perron technique prevents adding lagged difference terms by using non-parametric statistical methods to account for serial correlation in the error terms.

After establishing data stationarity, the Johansen (1988) co-integration technique is used to perform a co-integration test to see whether the equilibrium relationship exists. According to Gujarati and Porter (2009), cointegration is based on the assumption that when two or more non-stationary variables with a long-run relationship are regressed on each other, they will produce stationary outcomes for a linear combination of variables. We accept the alternative hypothesis and infer that cointegration occurs since the null hypothesis is rejected. 
The error correction model estimated using victor error correction model (VECM) is used to test the short run equilibrium connection. This study's VECM analysis is based on equation (3). ECM $\mathrm{t}_{\mathrm{t}-1}$ is a one-period lagged error correction term that contains residuals from the calculated cointegration model of equation. The ECM denotes the speed with which the cointegration model corrects its preceding period's disequilibrium or restores the long run equilibrium association.

Any short-run movement between the dependent and explanatory variables will converge back to the long-run association if the ECM $\mathrm{E}_{\mathrm{t}-1}$ coefficient is negative and significant. In equation (3), the symbol $\Delta$ denotes the first-differenced form of the variables in the model.

Diagnostic tests are used to confirm the model's goodness of fit. Diagnostic tests test for serial correlation and heteroscedasticity in the model.

\section{Results and Discussion.}

\subsection{The Unit Root Test.}

The presence of unit roots and the order of integration in all the variables were determined using Phillips-Perron (PP) unit root test, first in levels, first difference, and potential second difference.

Table 2. Unit Root Results.

\begin{tabular}{ccccc}
\hline Variables & PP Test & $\begin{array}{c}\text { Critical } \\
\text { Value }\end{array}$ & Status & Remark \\
\hline $\ln$ RGDP & 9.041164 & $-3.626784^{*}$ & $\mathrm{I}(0)$ & Stationary \\
$\ln \mathrm{CPS}$ & 5.026785 & $-3.626784^{*}$ & $\mathrm{I}(0)$ & Stationary \\
$\ln \mathrm{FDI}$ & 6.416575 & $-3.626784^{*}$ & $\mathrm{I}(0)$ & Stationary \\
$\ln \mathrm{GCE}$ & 10.48192 & $-3.626784^{*}$ & $\mathrm{I}(0)$ & Stationary \\
$\ln \mathrm{PI}$ & -3.913862 & $-3.632900^{*}$ & $\mathrm{I}(1)$ & Stationary \\
\hline
\end{tabular}

Note. $(*)$, indicate significant at $1 \%$. All the variables are log linearized. Source: Authors' computation

The PP unit root test discovered that $\ln \mathrm{PI}$ is non-stationary (has unit roots) at levels, so the null hypothesis of unit root for the variables cannot be rejected at levels; however, with the exception of $\ln \mathrm{RGDP}, \ln \mathrm{CPS}, \ln \mathrm{FDI}$, and $\ln \mathrm{GCE}$, which are stationary at levels, we reject the null hypothesis since the critical values are less than the PP test statistics at the $1 \%$ level of significance. As a result, we conclude that all of the gathered time series are stationary.

\subsection{Cointegration Estimate.}

After determining the order of integration, we looked for cointegration between the dependent (private investment as measured by credit to the private sector and foreign direct investment) and independent variables to see if a long-run link existed.

The co-integration findings for model I and model II (that is, credit to the private sector and foreign direct investment) are shown in tables 3 and 4, respectively. 
Table 3. Model I. Johansen Cointegration Test Results.

\begin{tabular}{cccccccc}
\hline $\begin{array}{c}\text { Hypothesized } \\
\text { No. of CE(s) }\end{array}$ & Eigenvalue & $\begin{array}{c}\text { Trace } \\
\text { Statistic }\end{array}$ & $\begin{array}{c}0.05 \\
\text { Critical } \\
\text { Value }\end{array}$ & Prob. & $\begin{array}{c}\text { Max- } \\
\text { Eigen } \\
\text { Statistic }\end{array}$ & $\begin{array}{c}0.05 \\
\text { Critical } \\
\text { Value }\end{array}$ & Prob. $^{* *}$ \\
\hline None* & 0.613517 & 61.43924 & 47.85613 & 0.0016 & 26.42406 & 27.58434 & 0.0083 \\
At most 1 & 0.436317 & 28.165707 & 29.79707 & 0.0762 & 14.42070 & 21.13162 & 0.0700 \\
At most 2 & 0.181781 & 8.101626 & 15.49471 & 0.4546 & 11.22050 & 14.26460 & 0.4866 \\
At most 3 & 0.030378 & 1.079726 & 3.841466 & 0.2988 & 1.626066 & 3.841466 & 0.2988 \\
\hline
\end{tabular}

Trace and Max tests indicate 1 cointegrating eqn(s) at the 0.05 level; ${ }^{*}$ denotes rejections of the hypothesis at the 0.05 level. Source: Authors' computation

Table 4. Model II. Johansen Cointegration Test Results.

\begin{tabular}{cccccccc}
\hline $\begin{array}{c}\text { Hypothesized } \\
\text { No. of CE(s) }\end{array}$ & Eigenvalue & $\begin{array}{c}\text { Trace } \\
\text { Statistic }\end{array}$ & $\begin{array}{c}0.05 \\
\text { Critical } \\
\text { Value }\end{array}$ & Prob. $^{* *}$ & $\begin{array}{c}\text { Max- } \\
\text { Eigen } \\
\text { Statistic }\end{array}$ & $\begin{array}{c}0.05 \\
\text { Critical } \\
\text { Value }\end{array}$ & Prob. $^{* *}$ \\
\hline None $^{*}$ & 0.700079 & 77.70981 & 47.85613 & 0.0000 & 42.14823 & 27.58434 & 0.0004 \\
At most 1 & 0.483396 & 35.56158 & 29.79707 & 0.0097 & 23.11675 & 21.13162 & 0.0259 \\
At most 2 & 0.203274 & 12.44483 & 15.49471 & 0.1368 & 7.953562 & 14.26460 & 0.3834 \\
At most 3* & 0.120430 & 4.491271 & 3.841466 & 0.0341 & 4.491272 & 3.841466 & 0.0341 \\
\hline
\end{tabular}

Trace and Max tests indicate 2 cointegrating eqn(s) at the 0.05 level; ${ }^{*}$ denotes rejections of the hypothesis at the 0.05 level. Source: Authors' computation.

The findings of Johansen cointegration based on the Trace Statistics and Maximum Eigenvalue Statistics to identify the order of integration are shown in Tables 3 and 4 . The cointegrated time series variables are shown to have a long run equilibrium relationship; at the $5 \%$ critical value, the Trace Statistics and Maximum Eigenvalue Statistics reveal one cointegrating vector in model I, and two cointegrating vectors in model II. As a result, the null hypothesis that none of the variables are cointegrated is rejected by both trace and Max. Eigenvalue.

\subsubsection{A comparison Co-Integration Estimate between public investment and private investment.}

The co-integration estimates for the two models (that is, credit to the private sector and foreign direct investment) revealed that the variables in Model I and Model II had long run co-integration relationships. Trace and Maximum Eigenvalue have one co-integrating in Model I, whereas Trace and Maximum Eigenvalue have two co-integrating in Model II.

\subsection{Long-Run Estimate between public investment spending and private investment.}

The normalized coefficients present the estimates of the two models (that is, credit to private sector and FDI) reported above, showed the existence of long run co-integration links among the variables using the normalized Johansen co-integrating equation that is based on the lowest log likelihood. Each model's long-run co-integrating equation is shown below.

Table 5. Model I: Long Run Co-integration Equation on Credit to Private Sector.

\begin{tabular}{cccc}
\hline CPS & PI & RGDP & GCE \\
\hline 1.000000 & 16.09867 & 388.5129 & -27.70021 \\
& $(11.0233)$ & $(110.791)$ & $(9.60747)$ \\
\hline
\end{tabular}

Source: Authors' computation. 
In the long run, the long run equation on credit to private sector as a measure of private investment revealed a positive relationship between public investment and credit to the private sector, as well as between RGDP and credit to private sector, while a negative relationship exists between GCE and credit to private sector. The aforementioned finding implies that public investment and RGDP crowd in private investment (a 1\% rise in public investment and RGDP would boost private investment by 11.02 percent and 110.79 percent, respectively), but GCE crowds out credit to private sector. In the long run, a $1 \%$ rise in GCE would reduce credit to the private sector by 9.61 percent.

Table 6. Model II: Long Run Co-integration Equation on Foreign Direct Investment.

\begin{tabular}{cccc}
\hline FDI & PI & RGDP & GCE \\
\hline 1.000000 & 19.01021 & 296.7571 & -73.17813 \\
& $(23.4999)$ & $(302.546)$ & $(29.6815)$ \\
\hline
\end{tabular}

Source: Authors' computation

Similarly, the long run equation on FDI as a measure of private investment revealed that public investment and RGDP had positive relationships with FDI, but government consumption expenditure (GCE) had a negative association. This simply means that public investment (PI) and RGDP attract (crowd in) FDI, whereas government consumption expenditure repels (crowds out) it.

\subsubsection{A Comparison Analysis of a Long Run Estimate: Model I and Model II Results.}

In Model I, the long run equation on CPS as a measure of private investment revealed that public investment and credit to private sector (private investment) had a positive relationship. Similarly, the long term equation for FDI as a measure of private investment in Model II revealed that public investment had a positive relationship with foreign direct investment (private investment). In both scenarios, this means that public investment crowds in private investment. In Model I, the long run estimate showed a positive relationship between private investment and RGDP. Similarly, Model II revealed a favorable link between RGDP and FDI. In both models, this means that RGDP crowds in private investment. There was a negative association between government consumption expenditure, credit to private sector, and FDI, among other findings. In other words, government consumption expenditure crowds out private investment.

This study used the short run error correction model of equation (3) to analyze the short run link between public investment and private investment in South Africa, in addition to the long run estimate. 


\subsection{Short Run Estimate.}

After confirming the presence of long cointegration linkages using the Johansen Maximum Likelihood technique, Error Correction Models were formulated and estimated.

Table 7. Model I: Short run regression estimate on Credit to Private Sector.

\begin{tabular}{ccccc}
\hline & Coefficient & Std. Error & t-Statistic & Pro. \\
\hline ECM(-1) & 0.012500 & 0.011591 & 1.078407 & 0.2897 \\
$\Delta \mathrm{CPS}(-1)$ & 0.263919 & 0.232197 & 1.136615 & 0.2650 \\
$\Delta \mathrm{PI}(-1)$ & -2.116452 & 1.275326 & -1.659538 & 0.1078 \\
$\Delta \mathrm{RGDP}(-1)$ & 36.28329 & 21.28660 & -1.704513 & 0.0990 \\
$\Delta \mathrm{GCE}(-1)$ & -1.721813 & 1.512055 & -1.138724 & 0.2641 \\
$\mathrm{C}$ & 38077.67 & 47533.86 & 0.801064 & 0.4296 \\
R-squared & 0.690790 & Mean dependent var & & 91832.74 \\
Adjusted R-squared & 0.637478 & S.D. dependent var & & 93284.11 \\
S.E. of regression & 56166.17 & Akaike info criterion & & 24.86482 \\
Sum squared resid & $9.15 \mathrm{E}+10$ & Schwarz criterion & & 25.95686 \\
Log likelihood & -429.1344 & Hannan-Quinn criter. & & 24.95686 \\
F-statistic & 12.95749 & Durbin-Watson stat & & 1.801932 \\
Pro(F-statistic) & 0.000001 & & & \\
\hline
\end{tabular}

Source: Authors' computation

The ECM (-1) coefficient of the cointegrated model with CPS as the dependent variable while PI, RGDP and GCE are short run coefficients. The findings demonstrate that the coefficient of the cointegrating connection in the ECM (-1) equation is positive and insignificant, indicating that there is no adjustment to the equilibrium; there is no long-run casualty from the three independent variables PI, RGDP, and GCE. We further discovered that the model's Durbin-Watson value was 1.801932, indicating that there is no autocorrelation in the model.

The short run ECM equation on credit to private sector as a measure of private investment revealed a negative (-2.116452) and insignificant relationship between PI and CPS. As a result, an increase in PI will result in a decrease in CPS. The given result implies that public investment crowds out private investment by -2.116452 .

Following the above, RGDP had a positive (36.28329) but insignificant connection with credit to private sector. As a result, an increase in RGDP would boost the value of credit to private sector (CPS). This demonstrates that during the study period, South Africa's RGDP crowds in private investment.

GCE and credit to private sector have a negative relationship. As a result of a unit increase in GCE, private investment (credit to private sector) falls by 1.721813 unit. Simply put, GCE crowds out private investment. 
Table 8. Model II: Short run regression estimate on Foreign Direct Investment.

\begin{tabular}{ccccc}
\hline & Coefficient & Std. Error & t-Statistic & Pro. \\
\hline ECM(-1) & -0.018770 & 0.007713 & -2.433423 & 0.0214 \\
$\Delta$ FDI(-1) & -0.439905 & 0.271657 & -1.619340 & 0.1162 \\
$\Delta$ PI(-1) & -4.455268 & 2.207732 & -2.018029 & 0.0529 \\
$\Delta$ RGDP(-1) & -16.68557 & 25.55904 & -0.652824 & 0.1569 \\
$\Delta$ GCE(-1) & -0.132076 & 2.782799 & -.0047461 & 0.9625 \\
C & 144719.3 & 85845.39 & 1.685814 & 0.1026 \\
R-squared & 0.685122 & Mean dependent var & & 68505.23 \\
Adjusted R-squared & 0.583936 & S.D. dependent var & & 147360.8 \\
S.E. of regression & 95052.20 & Akaike info criterion & & 25.91704 \\
Sum squared resid & $2.62 \mathrm{E}+11$ & Schwarz criterion & & 26.18368 \\
Log likelihood & -447.5483 & Hannan-Quinn criter. & & 26.00909 \\
F-statistic & 10.54363 & Durbin-Watson stat & & 1.618576 \\
Pro(F-statistic) & 0.000008 & & & \\
\hline
\end{tabular}

Source: Authors' computation

The ECM(-1) coefficient of -0.018770 is statistically significant since it has a negative sign. This reveals that a short-run departure from -0.018770 can be restored quickly. This result reveals that in the short run, the long-run in FDI is swiftly adjusted to equilibrium. We furthermore discovered that the model's Durbin-Watson value was 1.618576, indicating that there is no autocorrelation in the model.

In the short run ECM equation, public investment (PI) had a negative (-4.455268) and insignificant impact on FDI as a measure of private investment. As a result, a rise in public investment will result in a drop in FDI. The following finding implies that public investment crowds out private investment (one percent increase in public investment would reduce FDI by 4.455268).

Similarly, the ECM equation reveals that RGDP in South Africa has a negative (-16.68557) but nonsignificant association with foreign direct investment. As a result of a unit rise in RGDP, foreign direct investment falls by -16.68557 units. The above finding implies that during the study period, RGDP crowds out private investment in South Africa.

Following this, GCE had a small but insignificant negative (-0.132076) relationship with FDI. As a result, increasing GCE reduces the value of FDI. This simply means that government consumption expenditure crowds out private investment (FDI) by 0.132076 .

\subsubsection{A Comparison Analysis of a Short Run Estimate: Model I and Model II Results.}

A comparison of Model I and Model II's ECM(-1) equations revealed inconsistent results. Since ECM(-1) in Model I is positive (0.012500) but not significant, there is no adjustment to the equilibrium. Model II, on the other hand, has a significant ECM(-1) coefficient with the appropriate negative sign. Its coefficient of -0.018770 indicates that current FDI values respond quickly to changes in PI, RGDP, and GCE.

In both Model I and Model II, the linkage between public and private investment is comparable. According to the findings of the ECM, public investment has a negative association with private investment (as measured by credit to private and foreign direct investment). The findings suggest that in South Africa, public investment is crowding out private investment. These findings support the neoclassical economists' notion that public investment crowds out private investment. According to Erden and Holcombe (2005), if the public and private sectors race for the same resources in the 
economy, the costs of financing private investment grow while the accessibility of credit to the private sector drops, could potential crowd out private sector investment.

In Model I and Model II, the link between RGDP and private investment (as measured by credit to private and FDI) presented diverse findings. In model I, the ECM equation indicates a positive but insignificant link between RGDP and credit to private sector. This implies that credit to private sector has a positive impact on economic growth. RGDP, on the other hand, has a negative but not significant relationship with FDI in Model II, according to the ECM equation. FDI, in other words, has a detrimental impact on economic growth. The implication is that in Model I, RGDP crowds in credit to private sector, but in Model II, RGDP crowds out FDI.

In both Model I and Model II, the link between GCE and private investment is constant. GCE has a negative and insignificant association with credit to the private sector and foreign direct investment, according to the ECM equation. Simply put, government consumption expenditure crowds out private investment (credit to private sector and FDI).

\subsection{Wald Test.}

The Wald test was used to determine the statistical significance of the variables, with the goal of determining if there is any short-run causation between public investment, RGDP, government consumption expenditure, and private investment (as measured by credit to private sector and foreign direct investment).

Table 9. Model I Wald Test Results.

(a) Short-term impact of PI on CPS

\begin{tabular}{|c|c|c|c|}
\hline Test Statistic & Value & $\mathrm{df}$ & Probability \\
\hline F-statistic & 2.754066 & $(1,29)$ & 0.1078 \\
\hline Chi-square & 2.754066 & 1 & 0.0970 \\
\hline \multicolumn{3}{|c|}{ Null Hypothesis: $C(3)=0$} & \\
\hline Normalized & iction $(=0)$ & Value & Std. Err. \\
\hline \multicolumn{2}{|c|}{$\mathrm{C}(3)$} & -2.116452 & 1.275326 \\
\hline
\end{tabular}

(b) Short-term impact of RGDP on CPS

\begin{tabular}{cccc}
\hline Test Statistic & \multicolumn{1}{c}{ Value } & df & Probability \\
\hline F-statistic & 2.905365 & $(1,29)$ & 0.0990 \\
Chi-square & 2.905365 & 1 & 0.0883 \\
\hline \multicolumn{4}{c}{ Null Hypothesis: C $(4)=0$} \\
& Null hypothesis Summary \\
\hline
\end{tabular}

\begin{tabular}{ccc}
\hline Normalized Restriction $(=0)$ & Value & Std. Err. \\
\hline $\mathrm{C}(4)$ & 36.28329 & 21.28660 \\
\hline \multicolumn{2}{c}{ Restrictions are linear in coefficients. }
\end{tabular}

(c) Short-term impact of GCE on CPS

\begin{tabular}{cccc}
\hline Test Statistic & Value & Df & Probability \\
\hline F-statistic & 1.296693 & $(1,29)$ & 0.2641 \\
Chi-square & 1.296693 & 1 & 0.2548 \\
\hline
\end{tabular}

Null Hypothesis: C(5)=0 
Null hypothesis Summary

\begin{tabular}{ccc}
\hline Normalized Restriction $(=0)$ & Value & Std. Err. \\
\hline $\mathrm{C}(5)$ & -1.721813 & 1.512055 \\
\hline \multicolumn{3}{c}{ Restrictions are linear in coefficients. }
\end{tabular}

Restrictions are linear in coefficients.

Table 9 (a) shows the findings of the Wald Test, which was used to see if $\ln$ PI had any short-term effects on $\ln$ CPS. The results showed that $\ln$ PI had no impact on the $\operatorname{lnCPS}$ in the short run. Table 9(b) shows the findings of the Wald Test, which was used to see if $\ln$ RGDP had any short-run effects on $\ln$ CPS. The findings reveal that there is no short-run causation between $\ln$ RGDP and $\ln C P S$. Similarly, no short-run causality to CPS was seen in table 9 (c) $\ln$ GCE. This indicates that $\ln$ PI, $\ln$ RGDP, and GCE have no influence on $\ln \mathrm{CPS}$ in the short term.

Table 10. Model II Wald Test Results.

(a) Short-term impact of PI on FDI

\begin{tabular}{|c|c|c|c|}
\hline Test Statistic & Value & Df & Probability \\
\hline F-statistic & 4.072442 & $(1,29)$ & 0.0439 \\
\hline Chi-square & 4.072442 & 1 & 0.0426 \\
\hline \multicolumn{4}{|c|}{ Null Hypothesis: $C(3)=0$} \\
\hline \multicolumn{4}{|c|}{ Null hypothesis Summary } \\
\hline Normalized & iction $(=0)$ & Value & Std. Err. \\
\hline \multicolumn{2}{|c|}{$\mathrm{C}(3)$} & -4.455268 & 2.207732 \\
\hline \multicolumn{4}{|c|}{ Restrictions are linear in coefficients. } \\
\hline \multicolumn{4}{|c|}{ (b) Short-term impact of RGDP on FDI } \\
\hline Test Statistic & Value & Df & Probability \\
\hline F-statistic & 0.426180 & $(1,29)$ & 0.5190 \\
\hline Chi-square & 0.426180 & 1 & 0.5139 \\
\hline \multicolumn{4}{|c|}{ Null Hypothesis: $C(4)=0$} \\
\hline \multicolumn{4}{|c|}{ Null hypothesis Summary } \\
\hline Normalized & iction $(=0)$ & Value & Std. Err. \\
\hline \multicolumn{2}{|c|}{$\mathrm{C}(4)$} & -16.68557 & 25.55904 \\
\hline \multicolumn{4}{|c|}{ Restrictions are linear in coefficients. } \\
\hline \multicolumn{4}{|c|}{ Short-term impact of GCE on FDI } \\
\hline Test Statistic & Value & Df & Probability \\
\hline F-statistic & 0.002253 & $(1,29)$ & 0.9625 \\
\hline Chi-square & 0.002253 & 1 & 0.9621 \\
\hline \multicolumn{4}{|c|}{ Null Hypothesis: $C(5)=0$} \\
\hline \multicolumn{4}{|c|}{ Null hypothesis Summary } \\
\hline Normalized & iction $(=0)$ & Value & Std. Err. \\
\hline \multicolumn{2}{|c|}{$\mathrm{C}(5)$} & -0.132076 & 2.782799 \\
\hline
\end{tabular}

Restrictions are linear in coefficients.

The Wald test demonstrated that $\ln$ PI has a short run casualty impact on the $\ln$ FDI, as shown in Table 10 (a). This suggests that an increase in $\ln$ PI has a favorable influence on $\ln$ FDI in the short run. Table 10(b) shows the results of the Wald test, which was used to see if $\ln$ RGDP had any short-run effects on $\operatorname{lnFDI}$. The findings reveal that there is no short-run causation between $\ln \mathrm{RGDP}$ and $\ln$ FDI. 
Table 10 (c) $\ln$ GCE, on the other hand, indicated that $\ln$ FDI had no short-run causality. This means that in the short run, $\ln$ RGDP and $\ln$ GCE have no significant impact on $\ln$ FDI.

\subsubsection{A Comparison Analysis of a Wald Test: Model I and Model II Results.}

The Wald test was used to see if $\ln$ PI had any short-run effects on lnCPS. In model I, the results demonstrated that $\ln$ PI had no short-run casualty effect on the lnCPS. The Wald test, on the other hand, demonstrated that the $\ln \mathrm{PI}$ has a short-run casualty impact on the $\ln$ FDI in Model II. This suggests that an increase in $\ln \mathrm{PI}$ has a favorable influence on $\ln \mathrm{FDI}$ in the short run. Other findings reveal that there is no short-run causation between $\ln$ RGDP, $\operatorname{lnCPS}$, and $\ln$ FDI. In both model I and model II, $\ln$ GCE indicated that there is no short run causality between $\ln$ CPS and $\ln$ FDI.

\subsection{Diagnostic tests.}

Heteroskedasticity and autocorrelation over identification tests are used to confirm that the data used in model estimate is appropriate.

Table 11. CPS Model I: Residual Analysis Results

\begin{tabular}{ccc}
\hline \multicolumn{1}{c}{ Tests } & Values & P-values \\
\hline Breusch-Godfrey Serial LM & 0.709448 & 0.3996 \\
White's Heteroskedasticity & 33.61534 & 0.0588 \\
\hline
\end{tabular}

Source: Author's Computation

There is no serial correlation, according to the null hypothesis, and there is serial correlation, according to the alternative hypothesis. We cannot reject the null hypothesis of no autocorrelation if the $\mathrm{p}$ value is more than $5 \%$. The $\mathrm{p}$ value for lag one in the Breusch-Godfrey Serial LM test is greater than $5 \%(39.96 \%)$, indicating that we cannot reject the null hypothesis and that the model exhibits no autocorrelation. The $\mathrm{p}$ value for heteroscedasticity was determined to be 0.0588 , suggesting that the residuals are not heteroskedastic (Table 11).

Table 12. FDI Model II: Residual Analysis Results

\begin{tabular}{ccc}
\hline \multicolumn{1}{c}{ Tests } & Values & P-values \\
\hline Breusch-Godfrey Serial LM & 2.859041 & 0.909 \\
White's Heteroskedasticity & 34.27696 & 0.0543 \\
\hline
\end{tabular}

Source: Author's Computation.

Table 12 displays the outcome of the Breusch-Godfrey LM test, which reveals that the $p$ value for lag one is greater than $5 \%(90.9 \%)$, indicating that the null hypothesis cannot be rejected, implying that there is no serial correlation within the model. The $\mathrm{p}$ value for heteroscedasticity was determined to be 0.0543, suggesting that the residuals are not heteroskedastic (Table 12).

\section{Conclusion.}

The main objective of the study was to examine at the link between public and private investment in South Africa over the period of 40 years (1980-2020). Despite the fact that econometric methodologies differ, various authors have sought to determine if public investment does really crowds in or crowds out private investment. This relationship, on the other hand, has prompted debate among researchers and across ideologies. The balance between public and private investment has yet to be established. 
However, this article suggests that in South Africa throughout the studied time, public investment crowded out private investment.

The Phillips-Perron (PP) unit root test was used to determine stationarity. Apart from public investment (PI), which is stationary at first difference, the PP test findings show that other variables are stationary at levels. The co-integration test reveals that there is a long-run equilibrium relationship between variables, implying that cointegration occurs.

In the long run, the long run co-integration equation on credit to private sector as a measure of private investment revealed a positive link between public investment and private investment, as well as between RGDP and private investment, while there is a negative relationship between government consumption expenditure and private investment.

Similarly, the long run equation revealed that public investment and RGDP had positive relationships with foreign direct investment, whereas government consumption expenditure has a negative association with foreign direct investment.

Furthermore, the short run estimate of the $\operatorname{ECM}(-1)$ coefficient is positive but not significant, so there is no adjustment to the equilibrium in model I. Model II, on the other hand, had a statistically insignificant and negative short run estimate of the coefficient of error correction term. The error correction term's negative sign suggests a return to long run equilibrium from short run disequilibrium.

In both model I and model II, the ECM short run estimate revealed that public investment had a negative relationship with private investment (as measured by credit to private sector and foreign direct investment). As a result of the findings, public investment in South Africa is crowding out private investment. The findings support the assumption of neoclassical economists that public investment in South Africa crowds out private investment. Furceri and Sousa (2009), as well as Nazmi and Ramirez (1997), found a crowding out impact between public and private investment.

In model I, the short run estimate revealed that RGDP had a positive but insignificant relationship with credit to private sector. In Model II, on the other hand, RGDP exhibits a negative but nonsignificant association with foreign direct investment. This simply means that in Model I, RGDP crowds in credit to private sector, but in Model II, RGDP crowds out foreign direct investment in South Africa.

In both model I and model II, the short run estimate revealed that government consumption expenditure (GCE) had a negative link with credit to private sector and foreign direct investment. This simply means that GCE in South Africa crowds out credit to private sector and FDI.

The residuals are homoskedastic and show no serial correlation, indicating that the model is adequate, according to the test for adequacy. 


\section{References.}

Abel, A.B., and Eberly, J.C. (1995). The effect of irreversibility and uncertainty on capital accumulation.

NBERWorking Paper Series no. 5363. Cambridge, MA: National Bureau of Economic Research.

Abel, Andrew B. (1983). Optimal investment under uncertainty. American Economic Review, 73:228-33.

Ascharer, DA. (1989a). Does public capital crowd out private capital? Journal of Monetary Economics, $24: 171$ 188.

Aschauer, DA. (1989b). Is Public Expenditure Productive? Journal of Monetary Economics, 23, 167-200.

Atukeren E. (2004). Intrection between Public and Private Investment Evidence from Developing Countries, Kyklos.

Aubyn, M.S. and Afonso, A. (2008). Macroeconomic Rates of Return of Public and Private Investment: Crowdingin and Crowding -out Effects. Department of Economics, Technical University of Lisbon, Working Paper Number WP/06/2008/DE/UECE.

Belloc, M. and Vertova, P. (2004). How Does Public Investment Affect Economic Growth in HIPC? An Empirical Assessment. Universita’ degliStudi di Siena, Departimento Di Economia Politica, WP Number 416-Gennaio.

Brooks, C. (2008). Introductory Econometrics for Finance. Cambridge University Press. Cambridge

Budget Review. (2016). National Treasury, Republic of South Africa. http://www.treasury.gov.za/documents/national\%20budget/2016/review/chapter\%207.pdf [accessed on 19 January 2018].

Chete, LN., and Akpokodje, G. (1997). Micro Economic determinants of domestic private investment in Nigeria. An empirical exploration. CBN Economic and Financial Review, 35 (1): 43 - 57.

Dixit, A and Pindyck, RS. (1994). Investment under uncertainty. Princeton, NJ: Princeton University Press.

Ekpo, A.H. (1996). The public sector and Economic Growth in Nigeria". In: Fiscal and Monetary policy during structural adjustment in Nigeria proceedings of a seminar of national policy workshop. AETC/CBN.

Erden, L and Holcombe, R.G. (2005). The Effects of Public Investment on Private Investment in Developing Economies. Public Finance Review. 33(5), 575-602. http://dx.doi.org/10.1177/1091142105277627

Evans, P., and Karras, G. (1994). Are government activities productive? Evidence from a panel of U.S. states. Review of Economics and Statistics 76 (1): 1-11.

Fedderke J.W, Perkins P, Luiz J (2006). Infrastructural investment in long-run economic growth: South Africa 18752001. World Development, 34(6): 1037-1059.

Fielding D (1997). Aggregate investment in South Africa: A model with implications for political reform. Oxford Bull. Econ. Stat., 59(3): 349- 369.

Furceri D and Sousa R. M (2009). The Impact of Government Spending on Private Sector: Crowding-out versus Crowding-in Effects, Documentos de Trabalho Working paper series.

Gbenga, A., Babatunde, OO., and Esther, L .(2015). The Effect of Sectorial Public Investment Expenditure on Private Expenditure in Nigeria: An Error Correction Analysis. European Journal of Business and Social Sciences, 4,(04): $87-104$.

Ghura, D. (1997). Private Investment and Endogenous Growth: Evidence from Cameroon. International Monetary Fund, IMF Working Paper, WP/97/165.

Gujarati, D.N. and Porter, D.C. (2009). Basic Econometrics (International Edition).5th Edition. McGraw-Hill/Irwin.

Hague, ST. 2013. Effect of Public and Private Investment on Economic Growth in Bangladesh: An Econometric Analysis. Research Study Series No FDRS05/2013, Finance Division, Ministry of Finance.

Heymans, C. and Thome-Erasmus, J. (1998). Infrastructure: A foundation for Development - Key Points from the DBSA Development Report 1998. Development Southern Africa, 15 (4): 661 - 668.

Holtz-Eakin, D. (1994). Public-sector capital and productivity puzzle. Review of Economics and Statistics 76 (1): $12-$ 21.

Hussein, J and Benhin, J. (2015). Public and Private Investment and Economic Development in Iraq (1970-2010). International Journal of Social Science and Humanity, 5(9): 743-751. http://dx.doi.org/10.7763/IJSSH.2015.V5.550. 
Khan, M.S. and Reinhart, CM. (1990). Private investment and economic growth in developing countries. World Development, 18(1), 19-27.

Kollamparambil, U. and Nicolaou M. (2011). Nature and Association of Public and Private Investment: Public Policy Implication for South Africa. Journal of Economics and International Finance. 3(2); 98-108.

Kustepeli. (2005). Effectiveness of Fiscal Spending: Crowding Out and/or Crowding in?

Makuyana, G and Odhiambo, NM. (2016). Public and Private Investment and Economic Growth: A Review. Journal of Accounting and Management. 6(2); $25-42$.

Mbanda, V. and Chitiga, M. (2013). Growth and Employment Impacts of public Economic Infrastructure investment in South Africa: A dynamic CGE Analysis. Poverty and Economic Policy Network Working Paper.

Mittnik, S. and Newman, T. (2001). Dynamic Effects of Public Investment: Vector Autoregressive Evidence form Six Industrialized Countries. Empirical Economics, 26(2); 429-446.

Narayan, P.K. (2004). Do Public Investment Crowds Out Private Investment? Fresh evidence from Fiji. Journal of Policy Modeling, 2(6), 747-73.

Nazmi, N and Ramirez, MG. (1997). Public and Private Investment and Economic Growth in Mexico. 15, (1): 6575. http://dx.doi.org/10.1111/j.1465-7287.1997.tb00455.x

NPC (National Planning Commission). (2012). National Development Plan 2030. Our future - make it work. The Presidency of the Republic of South Africa. Cape Town: Shereno Printers.

Ricardo 1820 B.M. (1971). National Income and Price Level. New York: McGraw-Hill.

Sinevičienė, L. (2015). Testing the Relationship between Government Expenditure and Private Investment: The Case of Small Open Economies. Journal of Economics, Business and Management, 3, (6), 628-632.

Tatom, J.A. (1991). Public capital and private sector performance. Federal Reserve Bank of St. Louis. Review 73 (3): 3-15.

Toshiya, H. (2010). Crowding-in Effect of Public Investment on Private Investment. Policy Research Institute, Ministry of Finance, Japan, Public Policy Review.

Wang, B. (2005). Effects of Government Expenditure on Private Investment: Canada Empirical Evidence. Empirical Economics, 30(2); 493-504.

World Bank. (2017). South Africa Economic Update: Private Investment for jobs. Available at http://documents.worldbank.org/curated/en/509111484323988058/South-Africa-economic-update-privateinvestment-for-jobs (accessed 10 May 2017).

$\mathrm{Xu}, \mathrm{X}$ and Yan, Y. (2014). Does government investment crowd out private investment in China? Journal of Economic Policy Reform, 17(1), 1-12. http://dx.doi.org/10.1080/17487870.2013.866897. 